ks. Maciej Ostrowski ${ }^{1}$

Uniwersytet Papieski Jana Pawła II w Krakowie

\title{
Refleksja pastoralnoteologiczna nad dokumentem Stolicy Apostolskiej Przyjęcie Chrystusa w uchodźcach i przymusowo przesiedlonych
}

W związku z kryzysem emigracyjnym ogarniającym Europę rozwinęła się szeroka dyskusja dotycząca problemu migrantów. Sprawa jest złożona i wieloaspektowa. Autor artykułu chce włączyć się w tę dyskusję jako teolog pastoralista. Ma świadomość, że będzie to tylko skromny głos wśród licznych wypowiedzi polityków, dziennikarzy, przedstawicieli państwowych instytucji i naukowców różnych dziedzin. Ma nadzieję, że zwróci uwagę na niektóre uniwersalne wskazania podawane przez Kościół katolicki, które staną się wytyczną w rozwiązywaniu skomplikowanej kwestii. W okresie po drugiej wojnie światowej, która wywołała bodajże największe ruchy migracyjne notowane we współczesnej historii, Kościół wielokrotnie wypowiadał się na temat migracji i migrantów. Starał się opisać

1 Ks. prof. zw. dr hab. Maciej Ostrowski, dyrektor Instytutu Teologii Praktycznej oraz kierownik Katedry Teologii Pastoralnej na WT UPJPII; sekretarz Rady Konferencji Episkopatu Polski ds. Migracji, Turystyki i Pielgrzymek; specjalizuje się w problematyce pastoralnej z zakresu migracji, turystyki, pielgrzymowania, wolnego czasu, ekologii, parafii i ugrupowań kościelnych. E-mail: maciej.ostrowski@upjp2.edu.pl. 
problem i ocenić go w świetle katolickiego nauczania jako „znak czasu” oraz podać praktyczne wskazania co do jego rozwiązywania, i to nie tylko dla duszpasterstwa, ale wszystkich ludzi dobrej woli. Tak było począwszy od konstytucji apostolskiej Exsul familia (1952), poprzez m.in. instrukcję De pastorali migratorum cura (1969), coroczne papieskie orędzia na Światowy Dzień Migranta i Uchodźcy oraz instrukcję Erga migrantes caritas Christi (2004) ${ }^{2}$.

Autor skupi się na mało znanym dokumencie dwóch papieskich dykasterii: Rady ds. Migracji i Podróżnych oraz Rady Cor Unum ${ }^{3}$ zatytułowanym Przyjęcie Chrystusa w uchodźcach i przymusowo przesiedlonych. Wytyczne duszpasterskie, opublikowanym w 2013 roku$^{4}$. Sam fakt wspólnego wydania dokumentu przez dwa organy Stolicy Apostolskiej podkreśla wagę zagadnienia i podnosi jego rangę. Już tytuł tego pisma wskazuje na zacieśnienie szerokiej problematyki migrantów do tych, którzy opuścili swój kraj jako wygnani bądź uciekinierzy. Wydaje się, iż Stolica Apostolska chce podkreślić, że właśnie ta grupa osób współcześnie zasługuje na szczególną uwagę wśród wszystkich innych migracyjnych ruchów. Jest ona bowiem narażona na największe niebezpieczeństwa, a stąd godna wzmożonej troski. W tym miejscu warto zaznaczyć, że analizowany dokument jest aktualizacją wcześniejszej rzymskiej publikacji, wydanej w 1992 roku, zatytułowanej Problem uchodźców, wyzwanie dla solidarności5. Co prawda analizowany przez nas obecnie tekst traktuje o zacieśnionej grupie - uchodźców i przymusowo osiedlonych - jednakże jego nauczanie można z pewnymi zastrzeżeniami odnieść do wszystkich kategorii migrantów.

2 Teksty dokumentów w kilku językach są dostępne na stronach internetowych Stolicy Apostolskiej, a w polskim tłumaczeniu na stronie internetowej Rady Konferencji Episkopatu Polski ds. Migracji, Turystyki i Pielgrzymek www.migracja.episkopat.pl.

3 Obydwie rady w styczniu 2017 roku przestały istnieć, a ich kompetencje przejęła nowa Dykasteria ds. Integralnego Rozwoju Człowieka.

4 Polskie tłumaczenie dokumentu: Przyjęcie Chrystusa w uchodźcach i przymusowo przesiedlonych. Wytyczne duszpasterskie: http://migracja.episkopat.pl/wp-content/uploads/2017/01/ Przyjecie_Chrystusa.pdf (12.03.2017).

5 Por. Przyjęcie Chrystusa..., dok. cyt. Prezentacja dokumentu oraz n. 35. Dokument, do którego odwołują się wytyczne duszpasterskie Przyjęcie Chrystusa...: Pontificio Consiglio „Cor unum", Pontificio Consiglio della pastorale per i migranti e gli itineranti i rifugiati: Una sfida alla solidarieta' http://www.vatican.va/roman_curia/pontifical_councils/migrants/documents/rc_pc_migrants_doc_19920625_refugees_it.html (12.03.2017). 
Autor zamierza zanalizować i skomentować wybrane, według niego najistotniejsze teologiczne wątki kościelnego nauczania zawarte we wskazanym dokumencie. Znajdujemy je głównie we wprowadzeniu i jego pierwszej części. Pozostałe działy dokumentu w nikłym stopniu odwołują się do teologicznych przesłanek. Zawierają one opis współczesnych sytuacji uchodźców i przymusowo przesiedlonych, odwołują się do cywilnych rozstrzygnięć prawnych, by w końcu przejść do nakreślenia zobowiązań ciążących na państwach i społeczeństwach. W niewielkim stopniu rysują duszpasterskie zadania Kościoła i tylko tu wkraczają w teologiczne obszary. Choć z drugiej strony bliższy opis współczesnych kontekstów społecznych byłby interesujący dla teologii pastoralnej jako tzw. przesłanka kairologiczna (socjologiczna). Jednakże skromne ramy artykułu nie powalają rozwinąć wszystkich wątków zagadnienia. Teologiczna przesłanka przedstawiona w dokumencie opiera się na biblijnych źródłach, Tradycji oraz społecznym nauczaniu Kościoła ${ }^{6}$.

\section{Kategorie migrantów}

Współczesna burzliwa dyskusja społeczno-polityczna i zamęt wokół kwestii migrantów biorą się między innymi z braku klarownego rozróżnienia między różnymi rodzajami migracji. Trzeba przyznać, że owo rozróżnienie nie zawsze jest sprawą łatwą. W cytowanym dokumencie o uchodźcach zauważono niezwykłą złożoność zjawiska, które utrudnia podejmowanie skutecznych rozwiązań ${ }^{7}$. Charakteryzując bardzo ogólnie problem, wśród fali przemieszczających się - choćby współcześnie przez Europę - są migranci ekonomiczni. Jedni z nich poszukują lepszych warunków bytowania, w znaczeniu wyższego poziomu życia, wykształcenia i profitów ze swej pracy. Inni migrują, gdyż w ich własnej ojczyźnie brakuje nawet minimalnych środków do egzystencji. Niektórzy na skutek konfliktów zbrojnych stracili swoje domy, warsztaty pracy i pola. Są też tacy, którzy chcą połączyć się ze swymi rodzinami i których bliscy już

6 Przyjęcie Chrystusa..., dok. cyt., n. 5.

Przyjęcie Chrystusa..., dok. cyt., n. 1. 
wcześniej znaleźli się w innym kraju. Są wreszcie migranci, których siłą usunięto z ich kraju albo uciekający przed przemocą. Jednym i drugim grozi poważne niebezpieczeństwo, ze śmiercią włącznie, gdyby powrócili do swoich stałych miejsc zamieszkania. Są i tacy, których do ucieczki zmusiły elementarne katastrofy, np. trzęsienia ziemi, powodzie bądź susze. Ci także nie mają szansy na dalsze życie w swej ojczyźnie. Łatwo zauważyć, że jedne z grup migrantów znajdują się w sytuacji przymusowej, inne same wybierają opuszczenie domu. Do pełniejszego obrazu można by dodać działania ze strony przemytników ludzi zachęcających do wyjazdu bądź też wprost zajmujących się handlem ludźmi. W tych rzeszach znajduje się jakiś - zapewne śladowy - procent wysłanników grup terrorystycznych. To oni wywołują największy niepokój wśród obserwatorów zjawiska, zwłaszcza w krajach docelowych.

\section{Definicja uchodźców i przymusowo wysiedlonych}

Jak zauważyliśmy wcześniej, istotną rzeczą jest klarowne określenie grupy migrantów, na której mamy zogniskować swoją uwagę. Tytuł komentowanego dokumentu mówi o uchodźcach i przymusowo wysiedlonych. Zacytujmy jego fragment: „[...] niektóre osoby są zmuszone wyjechać z własnego kraju na skutek prześladowań, klęsk żywiołowych i ekologicznych lub też innych czynników powodujących ekstremalnie trudne sytuacje, także zagrożenie dla życia. Podczas gdy niektórzy chcą po prostu znaleźć lepsze warunki życia za granicą, inni decydują się opuścić swoją ojczyznę, ponieważ już dłużej nie widzą w niej możliwości godnego życia"».

Zauważamy, że autorzy dość ogólnie określają grupę, która będzie przedmiotem ich uwagi. Choć z drugiej strony zastrzegają, że rozróżnienia poszczególnych grup migrantów są trudne i istnieją „mieszane” przepływy migracyjne. Jest to pewnym mankamentem tekstu, który mimo wszystko powinien być bardziej doprecyzowany. Z kontekstu innych punktów dokumentu można jednakże wnioskować, że autorom chodzi o migran-

8 Przyjęcie Chrystusa..., dok. cyt., n. 1. 
tów znajdujących się pod jakąś presją, a zatem zmuszonych do wyjazdu bądź ucieczki z ojczyzny poprzez obiektywne lub subiektywne czynniki. Niektórzy z nich zostali wręcz przeniesieni lub wygnani przez różne siły ludzkie lub żywioły przyrody. W tym znaczeniu sformułowanie zgadza się z definicją konwencji genewskiej przyjętej w 1951 roku, określającą uchodźcę jako osobę, która opuściła kraj swojego stałego zamieszkania $\mathrm{z}$ „uzasadnionej obawy przed prześladowaniem z powodu swojej rasy, religii, narodowości, przynależności do określonej grupy społecznej lub przekonań politycznych" i nie chce lub nie może z powodu tych obaw tam powrócićs 9

Autor niniejszego artykułu usłyszał ciekawą definicję uchodźców, niezamieszczoną w oficjalnych dokumentach ani niepojawiającą się w komentarzach specjalistów. Pochodzi ona od praktyka, wieloletniego obserwatora zjawiska migracji oraz duszpasterza migrantów, stąd jest godna odnotowania. Według owego obserwatora rysem charakterystycznym uciekiniera jest to, że nie chce on zbytnio oddalać się od swego rodzinnego kraju. Chciałby bowiem, jak tylko warunki na to pozwolą, jak najprędzej znów powrócić do niego. Ta praktyczna definicja może stać się dobrą wskazówką w opisie interesującego nas problemu. Powstaje bowiem uzasadnione pytanie, czy uchodźcami można nazywać tych, którzy oddalają się od swego kraju setki, a nawet tysiące kilometrów i nie zamierzają do niego powrócić? Należałoby ich nazwać raczej migrantami poszukującymi lepszych warunków życia, a może wprost migrantami ekonomicznymi. W tym miejscu na marginesie warto zauważyć, co potwierdzałoby tę tezę, że wiele europejskich rządów (w tym polski) nie skłania się do przyjmowania uchodźców z terenów ogarniętych konfliktami. Natomiast uważają, że należy pomagać ludności tych krajów na miejscu, by mogli pozostać w swoich rodzinnych miejscowościach. Trzeba zatem według tej koncepcji skupiać się na politycznym wygaszaniu konfliktów, by usuwać przyczyny migracji.

9 Przyjęta przez ONZ w Genewie 28 lipca 1951 roku, http://www.unhcr-centraleurope. org/pl/pdf/materialy/konwencje/konwencja-dotyczaca-statusu-uchodzcow-z-1951-r/tekst-konwencji-z-1951-r.html (12.03.2017). 


\section{Biblijny nakaz przyjęcia cudzoziemców}

Analizowany dokument zwraca uwagę, że już w Starym Testamencie istniał w Izraelu nakaz przyjmowania cudzoziemców, a nawet traktowania ich jak współobywateli ${ }^{10}$. Warto podkreślić, że zapisany jest on w Pięcioksięgu Mojżeszowym, czyli wśród tekstów stanowiących zręby żydowskiego prawa. Jako argument autor natchnionej księgi przytacza fakt, że sami Izraelici kiedyś byli przybyszami w Egipcie, poszukującymi tam odpowiednich warunków do przeżycia. Udali się bowiem do Egiptu z powodu głodu i w poszukiwaniu żywności. Następnie zostali sprowadzeni na stałe do nowego kraju przez swego brata Józefa, który - choć niegdyś sprzedany w niewolę - uzyskał w nowym kraju wysoką pozycję społeczną i mógł zaprosić swoich braci do zamieszkania wraz z nim. W późniejszych dziesięcioleciach sytuacja się zmieniła. Rodzina Józefa rozrosła się w liczny naród i została poddana represjom. Uznano ich bowiem za zagrożenie dla rdzennych mieszkańców Egiptu ${ }^{11}$.

Interpretując tę historię we współczesnych kontekstach, powiedzielibyśmy, że Izraelici byli uchodźcami, których wygnała z własnego kraju elementarna klęska nieurodzaju i związanego z nią głodu. Był to też akt łączenia rodziny ${ }^{12}$. W dalszym ciągu można doszukiwać się w tej historii faktu odrzucenia obcych przybyszów i sprowadzenia ich do niższej kategorii społecznej niewolników, a to wszystko wobec rzeczywistych bądź domniemanych zagrożeń z ich strony.

Wobec tych trudnych doświadczeń zapisanych w pamięci narodu wybranego, jak zauważono dalej w komentowanym dokumencie, tekst objawiony domaga się, by nie tylko przyjmować cudzoziemców i traktować ich jak współobywateli, ale też nie łamać praw obcych, przybyszów, którzy zamieszkali w jego ziemi. Zwrócono w nim uwagę na nadprzyrodzony motyw takiego postępowania. Nakaz ten pochodzi ze spra-

10 Przyjęcie Chrystusa..., dok. cyt., n. 19. Powołano się na Kpł 19, 34; Pwt 24, 17-22.

11 Por. Wj 1, 8-10.

12 Kwestię tę jasno artykułuje analizowany dokument Przyjęcie Chrystusa... w punkcie 27. Zwraca on uwagę, że do pełnego i harmonijnego rozwoju człowiek potrzebuje rodziny. Ponadto podkreśla konieczność zagwarantowania podstawowych praw i godności każdej rodziny, także rodziny uchodźców. 
wiedliwości rozumianej biblijnie - jako posłuszeństwo prawu Bożemu ${ }^{13}$. Sprawiedliwość zatem ujmowana jest nie tylko jako czysto ludzki akt, najczęściej definiowany jako odpowiednie rozdzielanie wszystkim dóbr, bezstronność, uczciwość, poszanowanie praw bądź równe traktowanie wszystkich. Można skonstatować, że choć z perspektywy ludzkiej usprawiedliwia się sytuacje nieprzyjmowania obcych - migrantów, uchodźców - to jednak prawo Boże zobowiązuje chrześcijan do tego rodzaju działania. Istotne jest spojrzenie na sprawę z nadprzyrodzonej perspektywy, która nie zawsze koresponduje z ludzkimi ocenami i zapatrywaniami.

Godne podkreślenia jest zwrócenie uwagi w kontekście analizowanego dokumentu na fakt, że owo przyjęcie powinno mieć miejsce nawet w obliczu zagrożenia utraty czystości religijnej i tożsamości swego narodu. Tak rozumiały to biblijne nakazy Prawa ${ }^{14}$. Skądinąd wiadomo, jak ważna w historii narodu wybranego była troska o zachowanie wiary w jedynego Boga Jahwe. Jako że żył on otoczony nacjami pogańskimi, zawsze rodziło się niebezpieczeństwo złego wpływu ze strony pogańskich religii, pokusa naśladowania ich wierzeń, wypchnięcia własnej wiary i kultury oraz zastąpienia ich obcymi wzorami. W ten sposób naród utraciłby Boże wybranie i obietnicę, a zatem to, co składało się na jego tożsamość.

Zagrożenie obcymi wpływami trzeba pokonywać nie kategorycznym odrzuceniem przybyszów, lecz innymi sposobami. Komentowany dokument nie rozwija tej kwestii. Można jedynie domyślić się, że chodzi o uczciwy dialog międzykulturowy i międzyreligijny. Dialog, który prowadziłby nie do fałszywego irenizmu, zacierania różnic, ale wzajemnego poznania i ubogacenia posiadanymi wartościami. Taki dialog wymaga otwartości z obu stron - gospodarzy i przybyszów. Z drugiej strony, gdy odnosimy tę kwestię do zetknięcia chrześcijaństwa z innymi religiami, należałoby dążyć do umacniania wiary wśród chrześcijan, która wytrzymałaby próbę konfrontacji z obcymi, a nawet wrogimi wpływami.

13 Przyjęcie Chrystusa..., dok. cyt., n. 19. Powołano się na Kpł 19, 34; Pwt 1, 16; 24, 17; 27, 19.

14 Przyjęcie Chrystusa..., dok. cyt., n. 19. Dokument odnosi do Pwt 7, 3; 13, 6-9. 


\section{Godność ludzkiej osoby}

Istotnym argumentem zobowiązującym Kościół do troski o uchodźców i przymusowo przesiedlonych jest przekonanie o godności każdej ludzkiej osoby. Wywodzi się ono z nauczania zawartego już w pierwszej objawionej księdze, mówiącego, że wszyscy ludzie stworzeni są na obraz Boży i są jego dziećmi ${ }^{15}$. Stąd każdy człowiek ma nieocenioną wartość, jest cenniejszy od wszystkich innych materialnych rzeczy. Norma ta stanowi podstawę dla innych zasad i treści nauki społecznej Kościoła. Stąd Kościół czuje się zobowiązany bronić godności każdej osoby. Dokument przytacza słowa Benedykta XVI: „każdy emigrant jest osobą ludzką, która - jako taka - ma niezbywalne i podstawowe prawa, które powinni szanować wszyscy w każdej sytuacji" ${ }^{16}$. Naruszenie godności ludzkiej, jak dalej mocno podkreśla, powoduje cierpienie wszystkich członków Kościoła Ciała Chrystusowego ${ }^{17}$. Zatem rodzi się postulat pokonywania wszystkiego, co wywołuje owo cierpienie.

Każdy człowiek ma prawo do godnych warunków życia. Składają się na nie między innymi mieszkanie, ubranie, żywność, warunki wypoczyn$\mathrm{ku}$, opieka zdrowotna, jak też inne niezbędne świadczenia ze strony państwa na rzecz jednostki. Jeśli zatem jakaś osoba nie może cieszyć się godnym życiem we własnym kraju i godność ta jest zagrożona, ma ona prawo udać się gdzie indziej ${ }^{18}$. W tym momencie pojawia się problem, jak ocenić ów godny poziom życia. Trzeba przy tej ocenie pamiętać, że rozwój nie może być pojmowany wyłącznie materialnie jako „zrównanie poziomu życia wszystkich narodów z poziomem, który dziś osiągnęły kraje najbogatsze”, ale ma być rozumiany integralnie, np. poprzez rozwój „uzdolnień twórczych każdej poszczególnej osoby”. Jego szczytem jest „możliwość korzystania z prawa-obowiązku szukania Boga, poznawania Go

$15 \operatorname{Rdz} 1,26-27$.

16 Przyjęcie Chrystusa..., dok. cyt., n. 26 cytuje encyklikę Caritas in veritate, 62.

17 Przyjęcie Chrystusa..., dok. cyt., nn. 5 i 25.

18 Przyjęcie Chrystusa..., dok. cyt., n. 26. Dokument odnosi tu m.in. do nauczania encykliki Jana XXIII Pacem in terris (I, 2) oraz soborowej konstytucji Gaudium et spes (nn. 63, 65-66, 84, 87). 
i życia zgodnie z tym poznaniem"19. Równocześnie trzeba pamiętać, że istnieje szczególna forma ubóstwa, jaką jest „pozbawienie osoby ludzkiej podstawowych praw, w szczególności prawa do wolności religijnej, a także prawa do inicjatywy gospodarczej"20. Zatem powstaje kolejne pytanie, czy w każdym wypadku usprawiedliwione jest dążenie migrantów do polepszenia warunków ekonomicznych, a raczej ich pragnienie korzystania z profitów materialnych uzyskiwanych przez najbogatsze państwa? Z pewnością usprawiedliwione jest poszukiwanie takiego miejsca na świecie, gdzie będą oni mogli korzystać z podstawowych praw każdej ludzkiej osoby dążącej do rozwijania swoich uzdolnień, a zwłaszcza pielęgnowania religijnego życia zgodnie z przyjętą przez siebie wiarą. Nie wynika z tego jednak prawo do materialnego i ekonomicznego zrównania wszystkich ludzi na świecie. Dobrobyt materialny - przy założeniu, że został osiągnięty w uczciwy sposób - jest wynikiem wieloletnich wysiłków i wyrzeczeń danego społeczeństwa. Choć na bogatszych spoczywa obowiązek dzielenia się z uboższymi, nie oznacza to nieroztropnego rozdawania biedniejszym przybyszom dóbr materialnych bez żadnych wysiłków z ich strony. Niestety tego rodzaju rozwiązanie obserwuje się w niektórych krajach Europy i to wywołuje słuszny społeczny sprzeciw.

\section{Jedność ludzkiej rodziny}

Kolejnym argumentem przedstawianym w komentowanym dokumencie, przemawiającym za podjęciem troski o uchodźców i przymusowo przesiedlonych, jest przekonanie o jedności ludzkiej rodziny. Wyprowadzany jest on z analogicznych źródeł. Cała ludzkość pochodzi od jednego Boga Stworzyciela i ten fakt wskazuje, że trzeba ją traktowaćjako wielką wspólnotę. Dokument powołuje się na nauczanie katechizmowe, które jednoznacznie stwierdza: „dzięki wspólnemu początkowi rodzaj ludzki stanowi jedność" ${ }^{11}$. Eksplikował tę prawdę już św. Paweł w swym dialogu z poga-

\footnotetext{
19 Jan Paweł II, enc. Centesimus Annus, 29.

20 Jan Paweł II, enc. Sollicitudo rei socialis, 42.

21 Katechizm Kościoła Katolickiego, 360.
} 
nami, gdy wypowiedział swe słowa na ateńskim Areopagu: „Jesteśmy bowiem z Jego rodu" (Dz 17, 28). Stąd z wielkiej ludzkiej wspólnoty nie można wykluczyć żadnej osoby, kultury bądź ludu ${ }^{22}$.

Nie wszyscy uchodźcy są chrześcijanami, a zatem członkami Ciała Chrystusowego. W wypadku migrantów przynależących do tego samego Kościoła katolickiego (można to stwierdzenie rozszerzyć na wszystkie chrześcijańskie wyznania) trzeba jednoznacznie stwierdzić, że choć pochodzą z różnych narodów, pokoleń i języków ${ }^{23}$, stanowią jedno i nie powinni być dla siebie obcy. Tu za Janem Pawłem II autorzy analizowanego dokumentu zwracają uwagę, że źródłem owej jedności Kościoła „nie jest wspólne pochodzenie jego członków, ale Duch Pięćdziesiątnicy”24. To właśnie w dniu Zesłania Ducha Świętego ujawnił się cud wzajemnego zrozumienia i zespolenia mieszkańców różnych regionów świata przybyłych do Jerozolimy ${ }^{25}$. Członków Kościoła spajają silniejsze niż tylko naturalne więzy jednej ludzkiej rodziny. Jednoczy ich w sposób nadprzyrodzony Duch Święty, ciągle działający w Kościele i poprzez Kościół. Jedność ta wynika z przynależności do jednego „Mistycznego Ciała”, gdzie głową zespalającą cały organizm jest Jezus Chrystus $^{26}$, a pogłębia się poprzez sakramentalną komunię ${ }^{27}$. Stąd też Kościół - według teologicznej definicji - staje się „narzędziem zjednoczenia między ludźmi”. Według komentowanego dokumentu owe czynniki budujące horyzontalną wspólnotę Kościoła mają być podstawą jego powołania polegającego na rozszerzaniu jedności w całym świecie. Ma to dziś zastosowanie w obliczu szerzących się migracyjnych ruchów sprawiających mieszanie się różnych ludów, będących nierzadko źródłem międzyludzkich napięć. To powołanie realizuje się zwłaszcza przez „głoszenie Ewangelii miłości i pokoju”28. Stąd Kościół nie może dystansować się od sytuacji związanych z migracyjny-

22 Przyjęcie Chrystusa..., dok. cyt., nn. 9-10.

23 Por. Ap 7, 9.

24 Przyjęcie Chrystusa..., dok. cyt., n. 15.

25 Por. Dz 2, 5-12.

26 Por. 1 Kor 12, 27.

27 Przyjęcie Chrystusa..., dok. cyt., nn. 11-12.

${ }_{28}$ Przyjęcie Chrystusa..., dok. cyt., n. 15. Powołano się tu na Orędzie Jana Pawła II na Światowy Dzień Migranta z 31.07.1992 („L’Osservatore Romano” wyd. pol., nr 10 (1992), s. 8 , p. 6). 
mi ruchami, które we współczesnym świecie wywołują liczne sprzeczności i napięcia. Nosi on w sobie potencjał zdolny do pokonywania podziałów i ciągłego odbudowywania międzyludzkich więzów.

\section{Gościnność}

Autorzy dokumentu wskazują dalej na praktykowaną od zarania w Kościele cnotę gościnności, która rodzi się z przekonania, że ludzkość jest jedną rodziną. Przytaczają tu kilka nowotestamentowych tekstów $^{29}$. Zwracają uwagę, że przyjęcie i ugoszczenie podróżnych były obowiązkową praktyką w chrześcijańskich gminach, wypływającą wprost z Ewangelii i stanowiącą istotny element w postawie każdego chrześcijanina. Podkreślają, że prawdziwa gościna polega na przyjmowaniu nie tylko osób miłych dla gospodarzy, ale także sprawiających trudności, dotkniętych ubóstwem lub niepełnosprawnościami. Z przyjęciem powinno łączyć się współczucie wobec przybyszów i traktowanie ich z godnością. Zauważają dalej, że gościnność praktykowana przez chrześcijan przyczyniała się do pozytywnego przekształcania całych społeczeństw. Zaowocowała ona instytucjonalnymi dziełami, np. budową schronisk dla podróżnych, szpitali dla chorych i pielgrzymów, domów opieki, ale też zmieniała stosunki społeczne, rozbudzając poczucie odpowiedzialności za bliźnich. Warto podkreślić za autorami dokumentu, że sami chrześcijanie podczas podróży nierzadko byli i są zależni od gościnności, ucząc się zarazem właściwego korzystania z niej.

Cnota gościnności i dziś nie traci na wartości. Zauważmy, że bogate społeczeństwa, ku którym często zmierzają uchodźcy, cierpią na chorobę egoizmu i zamykania się w sobie. Stąd być może tak trudno im akceptować przyjęcie migrantów. Przyjęcie uchodźców jest niewątpliwie ciężarem społecznym i finansowym. Jednakże jego realizacja stanowi weryfikację autentyzmu chrześcijaństwa. Chrześcijanie i dzisiaj mają misję przekształcania postaw społecznych w duchu Ewangelii. W świetle wcześ-

29 Przyjęcie Chrystusa..., dok. cyt., nn. 22, 23-24; odniesiono się do: Łk 14, 12-14; Dz 16, 15 oraz 18, 27; Flm 16-17. 
niejszych stwierdzeń trzeba zauważyć, że gościnność jest procesem dwustronnym. Trzeba także przybywających do obcego kraju uchodźców uczyć akceptacji dla lokalnych wartości, porządku społecznego i praw tam rządzących. Nie jest to proces łatwy, wymaga czasu i otwartości z obydwu stron. Niestety pośpieszne działania, niestawianie wobec migrantów jasno zasad przyjęcia mogą przynieść wiele szkód społecznych. Z drugiej strony przybysze nie zawsze akceptują porządek społeczny i prawny krajów docelowych. Tworzą zamknięte wspólnoty, niejednokrotnie rodzaje getta, rządzące się własnymi prawami. To z kolei powoduje społeczne napięcia, a nawet rodzi akty przemocy. Integracja i asymilacja społeczna jest procesem długotrwałym i wymaga cierpliwości oraz długomyślności, a zwłaszcza otwartej postawy z obydwu stron - miejscowych mieszkańców i migrantów.

\section{Naśladowanie miłości Boga do ludzi}

Istotnym argumentem za przyjęciem uchodźców podkreślanym w komentowanym dokumencie jest naśladowanie miłości Chrystusa. Jego autorzy w wyraźny sposób nawiązują do wcześniej opublikowanej Instrukcji Papieskiej Rady ds. Migrantów i Podróżnych zawierającej już w samym tytule rzeczoną prawdę: Miłość Chrystusa do migrantów ${ }^{30}$. We wprowadzeniu do komentowanego obecnie dokumentu spotykamy osobny punkt zatytułowany Miłość Kościoła względem uchodźców ${ }^{31}$. Zatem punktem wyjścia argumentacji jest odwołanie się do miłości samego Boga, który okazuje ją wszystkim bez różnicy ludziom. Ta miłość urzeczywistniła się w osobie Jezusa Chrystusa. Stanowi ona fundament Ewangelii i społecznej nauki Kościoła. Jej cechą jest bezinteresowność. Ukierunkowana jest ona szczególnie ku najbardziej potrzebującym² ${ }^{32}$ a wśród nich ku cudzoziemcom,

30 Erga migrantes caritas Christi z 3 maja 2004 roku. Polskie tłumaczenie: Wydawnictwo TUM, Wrocław 2007, także http://migracja.episkopat.pl/wp-content/uploads/2016/12/ Erga-migrantes-caritas-Christi-PL.pdf (30.03.2017).

31 Przyjęcie Chrystusa..., dok. cyt., nn. 8-14.

32 Przyjęcie Chrystusa..., dok. cyt., n. 6. Odwołano się do encykliki Benedykta XVI Caritas in veritate, 2. 
którzy znajdują się w trudnej sytuacji, a nierzadko będących przedmiotem wyzysku. Autorzy przypominają działalność samego Jezusa otaczającego opieką , ,ubogich i maluczkich", ale także naukę zawartą już w Starym Testamencie, który wskazywał, że Bóg otacza słabych szczególną opieką i nie pozwala ich wykorzystywać ani gnębicíc ${ }^{33}$. Kościół zatem naśladuje miłość Chrystusa. Ale także każdy pojedynczy członek Kościoła, wyznawca Chrystusa, jest zobligowany do urzeczywistniania tego rodzaju postawy. Autorzy podkreślają, że miłość ta jest najpierw darem dla człowieka ze strony Boga, czyli rodzi się z Boga, jest łaską ${ }^{34}$. W ten sposób uzdalnia ona człowieka do działania w jej duchu, nawet w takich momentach, gdzie po ludzku byłoby to trudne do zrealizowania.

Jedni z najbardziej zagrożonych wśród ubogich i poddani cierpieniom to uchodźcy i przymusowo przesiedleni. Oni to właśnie znajdują się w centrum uwagi Chrystusa. 0 cierpieniach uchodźców, które są wyzwaniem dla wzmożonej miłości ze strony Kościoła, mówili wielokrotnie papieże ${ }^{35}$. Ojciec święty Franciszek często powraca do tych wątków, które poniekąd stanowią wiodący rys jego pontyfikatu. Sam wielokrotnie dawał praktyczne przykłady zainteresowania losem uchodźców, np. przyjmując w Watykanie rodziny uchodźców bądź odwiedzając ich obozy.

W obliczu oporów ze strony społeczeństw i rządów wobec przyjmowania uchodźców, które podnoszą różne przeszkody, zdawałoby się nie do pokonania, należy podkreślać teologiczną prawdę, że Boża łaska jest w stanie przezwyciężać rodzące się blokady i uzdalniać do wielkoduszności. Jest ona nadprzyrodzoną, prawdziwą siłą dodającą odwagi w trudnych momentach, wymagających wyjątkowej ofiarności ${ }^{36}$. Pobudza do praktykowania czynnej miłości. Jak podkreśliliśmy wyżej, jest to miłość bezinteresowna szukająca w pierwszym rzędzie dobra człowieka, ku któremu jest skierowana. W tym kontekście można postawić zarzut wobec niektórych europejskich państw przyjmujących migrantów ze względu na spodziewane korzyści, np. tanią siłą roboczą pozwalająca na utrzymanie

\footnotetext{
3 Przyjęcie Chrystusa..., dok. cyt., n. 20; Wj 22, 20-22; Pwt 10, 17-19; 24, 14; Jr 7, 6.

34 Przyjęcie Chrystusa..., dok. cyt., nn. 6 i 28.

35 Dokument przywołuje m.in. encyklikę Jana XXII Pacem i terris (nn. 104-108) oraz list apostolski Pawła VI Amoris Officio (1971, n. 669).

36 Por. Benedykt XVI, encyklika Caritas in veritate, 1.
} 
niektórych gałęzi gospodarki. Gdy ten ostatni argument staje się górujący, wówczas tworzą się napięcia i pogłębiają społeczne różnice. Migranci nierzadko traktowani są jako gorsza grupa społeczna. Z grupy migrantów wybiera się jednostki przydatne do pracy, a pozostałych usiłuje się odesłać do miejsca pochodzenia bądź relokować do innych krajów.

Komentując myśl twórców dokumentu odnoszącą się do nauczania Benedykta XVI, należy wyeksplikować prawdę, że praktykowanie miłości bliźniego otwiera drogę do spotkania się człowieka z Bogiem. I odwrotnie, „zamykanie oczu na bliźniego czyni człowieka ślepym również na Boga”37. Z pewnością zdechrystianizowanym społeczeństwom trudniej otworzyć się na uchodźców. Człowiek żyjący w głębokim związku miłości z Bogiem łatwiej skłoni się ku pomocy migrantom, choćby wymagało to z jego strony ofiary. Choć i tutaj odnotowujemy paradoks. Zdechrystianizowane społeczeństwa zachodniej Europy są gotowe przyjmować migrantów. Polska uważana za bardzo religijny kraj mocno sprzeciwia się przyjęciu.

\section{Rozpoznanie i przyjęcie Chrystusa}

Rozwijając dalej myśl o naśladowaniu miłości Boga, jak też wyrażanie miłości wobec Chrystusa poprzez akt przyjęcia uchodźców i przymusowo przesiedlonych, autorzy komentowanego dokumentu formułują bodajże najmocniejszy argument. Jak już podkreślaliśmy, znajduje się on w samym tytule pisma, stanowiąc niejako teologiczne streszczenie całości zapisu. W uchodźcach i przymusowo wysiedlonych należy najpierw rozpoznać samego Chrystusa. Wyraźne rozpoznanie jest podstawą do Jego przyjęcia. Wymaga to uważnego wczytania się w ewangeliczną przypowieść o sądzie ostatecznym $^{38}$. Według słów samego Chrystusa utożsamia się On szczególnie z każdym obcym i przybyszem. Komentowany dokument eksponuje podkreślaną w wielu miejscach naukę Kościoła o tym, że Chrystus poprzez swoje wcielenie zjednoczył się w pewien sposób z każdym człowiekiem. Przyjął On kondycję ludzką, by stać się bliskim człowiekowi, dzieląc

37 Przyjęcie Chrystusa..., dok. cyt., n. 8. Odwołuje się do encykliki Deus caritas est, n. 16.

38 Mt 25, 31-46. 
jego losy, szczególnie te trudne. Dokument przywołuje prolog Ewangelii św. Jana mówiący o Słowie, które stało się ciałem i zamieszkało między ludźmi ${ }^{39}$. Nawiązuje też do innego wymownego tekstu Apokalipsy, który mówi o Chrystusie „kołaczącym do drzwi”. Kto otworzy „drzwi swego serca", zakosztuje najgłębszej wspólnoty z $\mathrm{Nim}^{40}$. Przyjęcie zatem każdego migranta, czy to będzie uciekinier, czy przymusowo wysiedlony, jest akceptacją i przyjęciem Syna Bożego obecnego w nim ${ }^{41}$. Może to jednak uczynić człowiek głęboko wierzący.

Jak mogliśmy przekonać się podczas dotychczasowych analiz, w rozwiązywaniu trudnej kwestii przyjęcia uciekinierów dla chrześcijanina na pierwsze miejsce wysuwają się argumenty nie tyle humanitarne, ile płynące z wiary. Mają one najsilniejsze podstawy i nie ulegają ludzkim koniunkturom. Wiele innych motywów, również przytoczonych przez komentowany dokument, może być zaakceptowane także przez osoby spoza chrześcijaństwa, nawet niewierzących. Jednakże sedno argumentacji zawiera się w ewangelicznym myśleniu. W nim znajduje się grunt, który pozwoli w skuteczny sposób znaleźć drogę pozwalającą wyjść z meandrów współczesnych dyskusji o rozwiązywaniu problemu migrantów.

\section{Kilka pastoralnych wniosków}

Nie jest naszym celem rozwijanie wątku pastoralnych implikacji wynikających z treści komentowanego dokumentu. Wymagałoby to niejednego kolejnego artykułu. Nie można jednak przerwać teologicznych analiz bez zasygnalizowania choćby kilku najistotniejszych wskazań praktycznych dla Kościoła. Taka jest rola teologii pastoralnej. W kolejnych paragrafach dokumentu rozwinięto całą gamę wytycznych i dla Kościoła, i dla świeckich instytucji.

Kościół spełnia rolę wychowawczą wobec swych wyznawców, a pośrednio także wobec całego świata. Przynależy ona do istoty jego misji. Przez

\footnotetext{
39 Przyjęcie Chrystusa..., dok. cyt., n. 14.

40 Por. Ap 3, 20.

${ }^{41}$ Przyjęcie Chrystusa..., dok. cyt., n. 13 i 22.
} 
tę działalność Kościół może przyczynić się do zapobiegania wielu sytuacjom będącym przyczyną migracyjnych kryzysów. W tej dziedzinie dysponuje on wieloma narzędziami. Dokument mówi o profilaktyce, a nie tylko leczeniu objawów. A jest nią umacnianie sprawiedliwości i solidarności w każdym środowisku ludzkiej rodziny oraz praca nad zapobieganiem międzyludzkim konfliktom. Postulowane jest, jak to ciekawie wyrażono, tworzenie „kultury solidarności i współzależności” wbrew „kulturze podejrzliwości" ${ }^{42}$. Kościół może tworzyć przestrzeń dla rozbudowywania międzyludzkich kontaktów, które będą okazją do wzajemnego słuchania się. To będzie sprzyjać poznaniu i zbliżeniu między ludźmi oraz stanie się podstawą wzajemnej otwartości. Mówiliśmy już wcześniej o konieczności kształtowania postaw gościnności. Trzeba dodać wychowanie umiejętności dzielenia się dobrami materialnymi i czasem. Niekiedy zajdzie potrzeba demaskowania niesprawiedliwości, które stają się przyczyną konfliktów. W każdym przypadku ważne jest uwrażliwianie opinii publicznej na sprawę uchodźców i przymusowo przesiedlonych. Tę rolę pełnią choćby wspomniane liczne wypowiedzi kościelne (dokumenty, orędzia, listy, przemówienia).

W dalszym ciągu komentowanego dokumentu jego autorzy wymieniają ustanawianie koniecznych struktur dla duszpasterstwa uchodźców, które pozwolą na obecność wśród nich Kościoła i niesienie wielorakiej pomocy, a szczególnie skuteczne przekazywanie im Ewangelii. Do tego trzeba dodać tworzenie grup osób społecznie zaangażowanych w rzeczoną sprawę oraz materialnych funduszów, jak też konstruowanie konkretnych programów pomocowych.

Trzeba wspomnieć za komentowanym dokumentem konieczność troski o cierpiących nie tylko w sferze materialnej, ale i duchowej. O ile ta pierwsza jest niemal dla wszystkich oczywista, o tyle druga niekiedy może być słabo eksponowana. A przecież rolą Kościoła jest na pierwszym miejscu wsparcie duchowe wobec człowieka. Cierpieniem uciekinierów i przymusowo przesiedlonych - mówimy tu w pierwszym rzędzie o chrześcijanach - jest pozbawienie opieki duszpasterskiej, sakramentów, słowa Bożego i obecności kapłanów. Wszyscy oni przeżywają tragedie ducho-

42 Przyjęcie Chrystusa..., dok. cyt., n. 32 i 42. 
we rozstania z ojczyzną, rozłąki z rodziną, nierzadko stratę bliskich, traumę z powodu przemocy, wojny bądź przelewu krwi. Także i niechrześcijanom Kościół może tu nieść pociechę duchową.

$$
*^{*} *
$$

Autor artykułu skupił się na komentarzu do części pierwszej dokumentu Przyjęcie Chrystusa w uchodźcach i przymusowo przesiedlonych. Chciał w ten sposób uwypuklić teologiczne podstawy rozwiązywania problemu migrantów, a w szczególności zwrócić uwagę na nauczanie Kościoła wzywające do otwarcia się i przyjęcia uchodźców. Ma świadomość, że nie wyczerpał wszystkich zawartych tam wątków. Ma nadzieję, że zachęci do głębszego studium zarówno teologicznych fragmentów, jak i dalszych działów dokumentu, które prezentują bogaty materiał do refleksji nie tylko dla teologów i duszpasterzy, ale także innych instytucji, których problem dotyczy. Jest w nich mowa między innymi o sytuacji współczesnych uchodźców, różnych ich grupach, ich prawach i obowiązkach, zadaniach duszpasterstwa i organów państwowych. Wspomniano problemy nierzadko marginalizowane, a przecież palące: ofiary handlu ludźmi, osoby wykorzystywane seksualnie, ofiary pracy przymusowej, dzieci-żołnierzy, bezpaństwowców czy też osoby wewnętrznie przesiedlone. 


\section{Summary}

\section{Refleksja pastoralnoteologiczna nad dokumentem Stolicy Apostolskiej Przyjęcie Chrystusa w uchodźcach i przymusowo przesiedlonych}

Autor analizuje i komentuje mało znany dokument wydany przez Stolicę Apostolska. Skupia się na teologicznych wątkach zawartych w dokumencie, pomijając inne kwestie w nim zawarte. Zwraca uwagę na konieczność odróżnienia migrantów przymusowo wysiedlonych i uchodźców od innych kategorii, np. migrantów ekonomicznych. Wskazuje na teksty biblijne i te elementy społecznej nauki Kościoła, na które powołują się redaktorzy dokumentu, wzywając do przyjmowania i otoczenia troską uchodźców oraz przymusowo przesiedlonych. Wśród nich na pierwsze miejsce wysuwa się nauczanie o godności każdej ludzkiej osoby, o jedności całej ludzkiej rodziny, o naśladowaniu miłości Boga do każdego człowieka, o chrześcijańskiej gościnności. Najistotniejszym ewangelicznym motywem przyjmowania obcych jest rozpoznanie w nich osoby samego Chrystusa. Motywy te znajdują zatem najgłębsze uzasadnienie w wierze i są jej praktyczną weryfikacją. W komentarzach do fragmentów dokumentu autor odnosi się do charakterystycznych współczesnych sytuacji związanych z przyjmowaniem migrantów, odczytując je w teologicznym świetle, a w konkluzji formułuje kilka pastoralnych wskazań dla Kościoła.

Słowa kluczowe: migranci, uchodźcy, przymusowo przesiedleni, teologiczne motywy przyjęcia migrantów

\section{Pastoral-theological reflection on the document of the Holy See Welcoming Christ in Refugees and Forcibly Displaced Persons}

The author analyses and provides commentary on relatively unknown document issued by the Holy See "Welcoming Christ in Refugees and Forcibly Displaced Persons". $\mathrm{He}$ focuses solely on theological aspects leaving out the others and indicates the necessity of distinguishing forcibly displaced persons and refugees from migrants of other categories, for instance economic migrants. The author shows Biblical texts and these elements of Catholic social teaching, which have been recalled by the editors of the document and which call to welcome and take care of refugees and forcibly displaced persons. Among them, teaching on human dignity of each human person, unity of entire human family, imitating God's love for each human person, and finally, Christian hospitality is the most important. Further, the most significant evangelical reason for welcoming strangers is recognizing Christ alone in them. Thus, bringing to life this, what is implied by all these reasons deeply rooted in the faith is its practical verification. In commentaries on passages of the document the author refers to characteristic contemporary situations of welcoming migrants 
interpreting them in the light of the theology. In conclusion, he formulates some pastoral recommendations for the Catholic Church.

Keywords: migrants, refugees, forcibly displaced persons, theological reasons for welcoming migrants

\section{Bibliografia}

Benedykt XVI, Encyklika Caritas in veritate.

Cichy D., Uchodźcy w Kościele, Lublin 2016.

Jan XXIII, Encyklika Pacem in terris.

Jan Paweł II, Encyklika Centesimus annus.

Jan Paweł II, Encyklika Sollicitudo rei socialis.

Jan Paweł II, Orędzia na Światowy Dzień Migranta i Uchodźcy 1985-2005, oprac. W. Necel, Poznań 2009.

Kongregacja Biskupów, Instrukcja dotycząca duszpasterstwa wśród migrantów De pastorali migratorum cura, 22.08.1969, http://migracja.episkopat.pl/wp-content/ uploads/2017/01/de_pastorali_migratorum.pdf (12.03.2017).

Ludzie w drodze. Nauki teologiczne o migracjach i migrantach, red. D. Cichy, Warszawa 2012.

Misja Kościoła i migracje człowieka, red. D. Cichy, Warszawa 2014.

Necel W., Prawo migranta do specjalnego duszpasterstwa, Warszawa 2012.

Ostrowski M., Migration-ein neues Problem für die Seelsorge in Polen, „Pastoraltheologische Hefte" 9 (2016), s. 92-100.

Papieska Rada ds. Migrantów i Podróżnych, Instrukcja Erga migrantes caritas Christi, Miłość Chrystusa do migrantów, 3.05.2004, Wrocław 2007.

Papieska Rada ds. Migrantów i Podróżnych, Papieska Rada „Cor Unum”, Przyjęcie Chrystusa w uchodźcach i przymusowo przesiedlonych. Wytyczne duszpasterskie, 2013, http://migracja.episkopat.pl/wp-content/uploads/2017/01/Przyjecie_Chrystusa. $\operatorname{pdf}(12.03 .2017)$.

Pius XII, Konstytucja apostolska Exsul familia o duchowej opiece nad migrantami z 1 sierpnia 1952, http://migracja.episkopat.pl/wp-content/uploads/2017/01/ exsulfamilia.pdf (12.03.2017).

Pontificio Consiglio „Cor unum”, Pontificio Consiglio della pastorale per i migranti e gli itineranti i rifugiati: Una sfida alla solidarieta, 26.06.1992, http://www.vatican.va/ roman_curia/pontifical_councils/migrants/documents/rc_pc_migrants_doc_19920625_ refugees_it.html (12.03.2017). 